\title{
Hepatoprotective Effect of Eriobotrya japonica Leaf Extract and Its Various Fractions against Carbon Tetra Chloride Induced Hepatotoxicity in Rats
}

\author{
Abdelaaty A. Shahat $\mathbb{D}^{1,2}$ Riaz Ullah $\mathbb{D}^{1,},{ }^{1,3}$ Ali S. Alqahtani ${ }^{1},{ }^{1}$ Mansour S. Alsaid, \\ Husseiny A. Husseiny, ${ }^{4}$ and Osaid T. R. Al Meanazel ${ }^{5}$ \\ ${ }^{1}$ Department of Pharmacognosy (Medicinal, Aromatic \& Poisonous Plants Research Center (MAPPRC), College of Pharmacy, \\ King Saud University, Riyadh 11451, Saudi Arabia \\ ${ }^{2}$ Phytochemistry Department, National Research Centre, 33 El Bohouth St., P.O. Box 12622, Dokki, Giza, Egypt \\ ${ }^{3}$ Department of Chemistry, Government College Ara Khel FR, Kohat, KPK, Pakistan \\ ${ }^{4}$ Faculty of Pharmacy, Misr University for Science and Technology (MUST), 6th of October City, Giza, Egypt \\ ${ }^{5}$ Pharmaceutical Department, College of Pharmacy, King Saud University, Riyadh, Saudi Arabia
}

Correspondence should be addressed to Riaz Ullah; rullah@ksu.edu.sa and Ali S. Alqahtani; alalqahtani@ksu.edu.sa

Received 4 August 2018; Revised 22 November 2018; Accepted 5 December 2018; Published 16 December 2018

Academic Editor: Danilo Ranieri

Copyright (C) 2018 Abdelaaty A. Shahat et al. This is an open access article distributed under the Creative Commons Attribution License, which permits unrestricted use, distribution, and reproduction in any medium, provided the original work is properly cited.

\begin{abstract}
Eriobotrya japonica is traditionally used as an antipyretic, digestive, and diuretic agent. Its flowers possess free radical-scavenging, antioxidative, and hepatoprotective effects. We investigated the hepatoprotective potential of $E$. japonica leaf extract and its various fractions against hepatotoxicity in rats. Liver injury was stimulated by the oral administration of carbon tetrachloride $\left(\mathrm{CCl}_{4} ; 2.5\right.$ $\mathrm{mL} / \mathrm{kg}$ b.wt.). Male albino rats $(\mathrm{n}=55)$ were distributed arbitrarily into 11 groups: Group I, normal control group; Group II, CCl (positive control group); Group III, $\mathrm{CCl}_{4}+$ silymarin; Groups IV and V, $\mathrm{CCl}_{4}+$ two doses of 250 and $500 \mathrm{mg} / \mathrm{kg}$ of the $80 \%$ methanolic extract of E. japonica leaves, respectively; Groups VI and VII, $\mathrm{CCl}_{4}+250 \mathrm{mg} / \mathrm{kg}$ and $500 \mathrm{mg} / \mathrm{kg}$ of the ethyl acetate fraction, respectively; Groups VIII and IX, $\mathrm{CCl}_{4}+250$ and $500 \mathrm{mg} / \mathrm{kg}$ of the butanol fraction, respectively; and Groups X and $\mathrm{XI}, \mathrm{CCl}_{4}+250$ and $500 \mathrm{mg} / \mathrm{kg}$ of the aqueous fraction of E. Japonica leaves, respectively. $\mathrm{CCl}_{4}$-treated rats that were given 250 or $500 \mathrm{mg} / \mathrm{kg}$ of the methanol extract of E. Japonica leaves, or its ethyl acetate, butanol, or aqueous fractions, had significantly lower levels of biochemical parameters such as alanine aminotransferase, aspartate transaminase, alkaline phosphate, total protein, gamma-glutamyl transferase, and bilirubin levels than those of the $\mathrm{CCl}_{4}$ positive group. However, the extract and fractions did not significantly affect lipid profiles. Thus, we conclude that Eriobotrya leaf extract and its fractions have a hepatoprotective effect against $\mathrm{CCl}_{4}$-induced hepatotoxicity in rats.
\end{abstract}

\section{Introduction}

Medicinal plants and their extracts represent a rich source of crude medications that possess therapeutic properties. Indeed, the World Health Organization reports that various plant fractions and their dynamic constituents are utilized as traditional medicines by $80 \%$ of the world population [1]. One such plant is Eriobotrya japonica, commonly known as loquat, an evergreen plant that belongs to the family Rosaceae.

Eriobotrya japonica originated in southeast China, but it is now grown in India, Japan, Korea, and other countries. It is small in size, with narrow leaves that are light in color on the underside and darker green on the upper surface. The leaves are valuable for the treatment of incessant maladies such as dysmenorrhea, lower back pain, asthma, chronic bronchitis, asthma, phlegm, and headache [2]. In Japan, loquat leaves have traditionally been used as antipyretic, digestive, and diuretic agents [3].

A variety of natural compounds such as tannins, megastigmane glycosides, triterpenes, sesquiterpenes, and flavonoids have been found in the leaves of E. japonica. Several of those compounds are active against viruses, inflammation, 
hyperglycemia, and tumors [2, 4-6]. Spectral methods have determined that the primary bioactive compounds of $E$. japonica leaves are tormentic acid, oleanolic acid, maslinic acid, ursolic acid, and corosolic acid [7]. Previous studies have shown that tormentic acid has normoglycemic, hypoglycemic, antiatherogenic, anti-inflammatory, and anticancer effects; and it reduces vascular smooth muscle cell expansion $[8,9]$.

The hydroalcoholic extracts of E. japonica flowers possess free radical-scavenging, antioxidative, and hepatoprotective effects against mercuric chloride induced hepatotoxicity in rats $[10]$.

To explore the possible scavenging capacity and hepatoprotective effects of E. japonica, we injected male rats with carbon tetrachloride $\left(\mathrm{CCl}_{4}\right)$, an extremely lethal chemical compound that is commonly used for inducing hepatotoxicity in animal studies [11, 12]. Then, the effects of an $80 \%$ methanol extract of E. japonica leaves, as well as its ethyl acetate, butanol, and aqueous fractions, against $\mathrm{CCl}_{4}$-induced hepatotoxicity were investigated. In this way, we aimed to scientifically validate and support the conventional uses and previous findings of E. japonica.

\section{Material and Methods}

2.1. Plant Materials and Authentication. In April 2016, the leaves of E. japonica were collected from Wadi Houf, Helwan, Egypt, and taxonomically confirmed by Professor Ibrahim Elgarf, Professor of Taxonomy, Faculty of Science, Cairo University, Cairo, Egypt.

2.2. Extraction. Dried shade leaves were powdered (1000 g) and extracted with $80 \%(\mathrm{v} / \mathrm{v})$ methanol and then vacuumconcentrated under reduced pressure at $40 \pm 1^{\circ} \mathrm{C}$ until dry. The residue was designated as methanolic extract (Er-1). A portion of Er-1 (70 g) was dissolved in water and fractionated successfully with hexane, chloroform, ethyl acetate (Er-2), and butanol (Er-3); the remaining aqueous solution was designated as Er-4.

2.3. Chemicals and Kits. Antioxidants, formalin, $\mathrm{CCl}_{4}$, isoflurane, and other chemicals were procured from El-Gomhouria Company, Cairo, Egypt. Kits used for biochemical analysis of alkaline phosphate (ALP), alanine aminotransferase (ALT), aspartate transaminase (AST), total protein, gammaglutamyl transferase (GGT), bilirubin, cholesterol, triglycerides, high density lipoprotein (HDL), malondialdehyde (MDA), nonprotein sulfhydryl groups (NP-SH), and total protein were obtained from the Gamma Trade Company for Pharmaceutical and Chemicals, Dokki, Egypt.

2.4. Induction of Hepatotoxicity. Liver damage was induced by subcutaneous injections of $\mathrm{CCl}_{4}(2 \mathrm{~mL} / \mathrm{kg})$ [13].

2.5. Test Groups. Rats were acclimated to animal laboratory conditions at $25^{\circ} \mathrm{C}, 55 \%$ humidity, and a $12 \mathrm{~h}: 12 \mathrm{~h}$ light-dark cycle for seven days prior to testing. Water was supplied ad libitum, and the rats were fed a basal diet for the entirety of the study. Afterward, 55 male rats (Laboratory Animal
Colony, Helwan, Egypt) were randomly divided into 11 groups as follows. In Group I, rats were subcutaneously injected with paraffin oil and then marked as the normal control group. In Group II, rats were subcutaneously injected with $\mathrm{CCl}_{4}$ ( $2 \mathrm{~mL} / \mathrm{kg}$ b.wt.) and then marked as the positive control group. In Group III, rats were subcutaneously injected with $\mathrm{CCl}_{4}(2 \mathrm{~mL} / \mathrm{kg}$ b.wt.) and silymarin $10 \mathrm{mg} / \mathrm{kg}$. Silymarin is the most used natural constituent for the healing of hepatic diseases worldwide due to its antifibrotic, anti-inflammatory, and antioxidant activities. Silymarin functions by stabilizing biological membranes and increasing protein synthesis [14]. Therefore, it is used as a standard drug around the world for hepatoprotective experiments.

In Groups IV and V, rats were subcutaneously injected with $\mathrm{CCl}_{4}(2 \mathrm{~mL} / \mathrm{kg}$ b.wt.) and Er-1 (250 and $500 \mathrm{mg} / \mathrm{kg}$, respectively). In Groups VI and VII, rats were subcutaneously injected with $\mathrm{CCl}_{4}(2 \mathrm{~mL} / \mathrm{kg}$ b.wt.) and Er-2 (250 and $500 \mathrm{mg} / \mathrm{kg}$, respectively). In Groups VIII and IX, rats were subcutaneously injected with $\mathrm{CCl}_{4}(2 \mathrm{~mL} / \mathrm{kg}$ b.wt. $)$ and Er3 (250 and $500 \mathrm{mg} / \mathrm{kg}$, respectively). In Groups X and XI, rats were subcutaneously injected with $\mathrm{CCl}_{4}(2 \mathrm{~mL} / \mathrm{kg}$ b.wt. $)$ and Er-4 (250 and $500 \mathrm{mg} / \mathrm{kg}$, respectively). Experiments were performed in Biology Lab of Medicinal Aromatic and Poisonous Plants Research Center College of Pharmacy King Saud University, Saudi Arabia, April-June 2018.

At the end of four weeks, food (but not water) was withheld from all animals for $12 \mathrm{~h}$. All rats were sacrificed with isoflurane. Blood samples were collected in clean centrifuge tubes via cardiac puncture. The samples were centrifuged at $3000 \mathrm{rpm}$ for $15 \mathrm{~min}$ to separate the serum. The serum was carefully removed and transferred into lavender test tubes and solidified at $20^{\circ} \mathrm{C}$ until utilization for biochemical experiments.

The livers of all test rats were divided into two; one half was immediately used for biochemical analysis, and the second half was subjected to histopathology examination.

2.6. Biochemical Analysis. Biochemical parameters such as ALT, AST, GGT, bilirubin, and ALP were calculated with the help of Reflotron Plus analyzer and commercially available kits (Roche) [15]. Commercial diagnostic kits were used to assess lipid profiles for levels of compounds such as aggregate cholesterol, triglyceride, HDL, very low-density lipoprotein (VLDL), and low-density lipoprotein (LDL) [16]. The methods described by Ullah [15] were used to determine the serum concentrations of MDA, NP-SH, and serum total protein.

2.7. Histological Study. All animals were euthanized under isoflurane anesthesia and then sacrificed. Small samples of liver, kidney, and testis were immediately sliced. The sections were fixed in $10 \%$ formol saline for $24 \mathrm{~h}$ and then bathed in tap water, dried in increasing concentrations of ethanol, cleaned in xylene, and inserted in paraffin wax (melting point of $55-60^{\circ} \mathrm{C}$ ). Then, $6 \mu \mathrm{m}$ thick segments were primed and stained with hematoxylin and eosin [17].

2.8. Statistical Analysis. Data are shown as the mean \pm standard error. The level of statistical significance $(\mathrm{P}<0.05, \mathrm{P}$ 
TABLE 1: Effect of various E. Japonica leaf extracts and fractions on serum marker enzymes in control and experimental rats.

\begin{tabular}{|c|c|c|c|c|c|}
\hline \multirow[b]{2}{*}{ Parameters } & \multicolumn{5}{|c|}{ Groups } \\
\hline & $\begin{array}{c}\text { AST } \\
\text { U/L }\end{array}$ & $\begin{array}{c}\text { ALT } \\
\text { U/L }\end{array}$ & $\begin{array}{c}\text { ALP } \\
\text { U/L }\end{array}$ & $\begin{array}{l}\text { GGT } \\
(\mathrm{U} / \mathrm{L})\end{array}$ & Bilirubin (g/dL) \\
\hline Normal & $107.33 \pm 3.09$ & $26.08 \pm 1.51$ & $341.00 \pm 7.13$ & $5.71 \pm 0.24$ & $0.57 \pm 0.01$ \\
\hline $\mathrm{CCl}_{4}$ & $339.16 \pm 5.28^{* * * a}$ & $301.00 \pm 6.00^{* * * a}$ & $586.33 \pm 7.77^{* * * a}$ & $17.70 \pm 0.87^{* * * a}$ & $2.94 \pm 0.06^{* * * a}$ \\
\hline Silymarin $10 \mathrm{mg} / \mathrm{kg}+\mathrm{CCl}_{4}$ & $154.66 \pm 4.95^{* * * b}$ & $88.15 \pm 6.47^{* * * \mathbf{b}}$ & $396.6 \pm 711.61^{* * * b}$ & $7.31 \pm 0.21^{* * * b}$ & $1.00 \pm 0.04^{* * * \mathbf{b}}$ \\
\hline $\mathrm{Er}-1250 \mathrm{mg} / \mathrm{kg}+\mathrm{CCl}_{4}$ & $333.66 \pm 5.25^{\mathrm{b}}$ & $295.83 \pm 5.24^{\mathrm{b}}$ & $584.50 \pm 7.96^{\mathbf{b}}$ & $15.66 \pm 0.55^{\mathbf{b}}$ & $2.95 \pm 0.04^{\mathrm{b}}$ \\
\hline $\mathrm{Er}-1500 \mathrm{mg} / \mathrm{kg}+\mathrm{CCl}_{4}$ & $314.33 \pm 5.40^{* \mathbf{b}}$ & $291.66 \pm 5.09^{\mathbf{b}}$ & $570.00 \pm 8.70^{\mathbf{b}}$ & $15.23 \pm 0.35^{* \mathbf{b}}$ & $2.79 \pm 0.04^{\mathrm{b}}$ \\
\hline $\mathrm{Er}-2250 \mathrm{mg} / \mathrm{kg}+\mathrm{CCl}_{4}$ & $278.33 \pm 6.08^{* * * b}$ & $196.50 \pm 6.33^{* * * \mathbf{b}}$ & $492.3 \pm 5.2^{* * * \mathbf{b}}$ & $12.71 \pm 0.35^{* * * \mathbf{b}}$ & $1.85 \pm 0.06^{* * * \mathbf{b}}$ \\
\hline $\mathrm{Er}-2500 \mathrm{mg} / \mathrm{kg}+\mathrm{CCl}_{4}$ & $194.16 \pm 5.46^{* * * \mathbf{b}}$ & $156.66 \pm 5.32^{* * * \mathbf{b}}$ & $441.0 \pm 6.24^{* * * \mathbf{b}}$ & $10.41 \pm 0.26^{* * * \mathbf{b}}$ & $1.40 \pm 0.03^{* * * \mathbf{b}}$ \\
\hline $\mathrm{Er}-3250 \mathrm{mg} / \mathrm{kg}+\mathrm{CCl}_{4}$ & $265.50 \pm 8.55^{* * * \mathbf{b}}$ & $170.16 \pm 7.21^{* * * \mathbf{b}}$ & $468.0 \pm 8.1^{* * * \mathbf{b}}$ & $10.11 \pm 0.24^{* * * \mathbf{b}}$ & $1.81 \pm 0.07^{* * * \mathbf{b}}$ \\
\hline $\mathrm{Er}-3500 \mathrm{mg} / \mathrm{kg}+\mathrm{CCl}_{4}$ & $198.50 \pm 4.77^{* * * \mathbf{b}}$ & $137.16 \pm 3.09^{* * * \mathbf{b}}$ & $428.1 \pm 6.44^{* * * \mathbf{b}}$ & $8.55 \pm 0.35^{* * * \mathbf{b}}$ & $1.23 \pm 0.05^{* * * \mathbf{b}}$ \\
\hline $\mathrm{Er}-4250 \mathrm{mg} / \mathrm{kg}+\mathrm{CCl}_{4}$ & $318.50 \pm 8.00^{\mathbf{b}}$ & $310.50 \pm 4.50^{\mathbf{b}}$ & $594.50 \pm 7.39^{\mathbf{b}}$ & $16.76 \pm 0.53^{b}$ & $2.98 \pm 0.04^{b}$ \\
\hline $\mathrm{Er}-4500 \mathrm{mg} / \mathrm{kg}+\mathrm{CCl}_{4}$ & $297.3 \pm 5.14^{* * * \mathbf{b}}$ & $292.33 \pm 5.00^{\mathbf{b}}$ & $582.83 \pm 15.47^{\mathbf{b}}$ & $16.06 \pm 0.84^{\mathrm{b}}$ & $2.82 \pm 0.05^{\mathrm{b}}$ \\
\hline
\end{tabular}

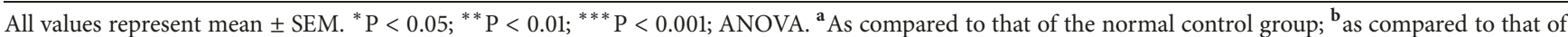
the $\mathrm{CCl}_{4}$ positive control group.

TABLE 2: Effect of E. Japonica leaf extract and fractions on metabolism and serum lipoproteins in control and experimental rats.

\begin{tabular}{|c|c|c|c|c|c|}
\hline \multirow[b]{2}{*}{ Parameters } & \multicolumn{5}{|c|}{ Groups } \\
\hline & $\begin{array}{c}\text { Cholesterol } \\
(\mathrm{mg} / \mathrm{dL})\end{array}$ & $\begin{array}{l}\text { Triglycerides } \\
\quad(\mathrm{mg} / \mathrm{dL})\end{array}$ & $\begin{array}{c}\text { HDL } \\
(\mathrm{mg} / \mathrm{dL})\end{array}$ & $\begin{array}{c}\text { LDL } \\
(\mathrm{mg} / \mathrm{dL})\end{array}$ & $\begin{array}{l}\text { VLDL } \\
(\mathrm{mg} / \mathrm{dL})\end{array}$ \\
\hline Normal & $108.3 \pm 3.08$ & $81.88 \pm 2.41$ & $47.56 \pm 1.14$ & $44.39 \pm 3.09$ & $16.37 \pm 0.48$ \\
\hline $\mathrm{CCl}_{4}$ & $231.5 \pm 8.5^{* * * a}$ & $187.83 \pm 3.87^{* * * a}$ & $22.93 \pm 0.95^{* * * a}$ & $171.0 \pm 8.19^{* * * a}$ & $37.56 \pm 0.77^{* * * a}$ \\
\hline Silymarin $10 \mathrm{mg} / \mathrm{kg}+\mathrm{CCl}_{4}$ & $128.5 \pm 3.5^{* * * \mathbf{b}}$ & $104.51 \pm 3.56^{* * * \mathbf{b}}$ & $44.6 \pm 1.30^{* * * \mathbf{b}}$ & $62.9 \pm 3.5^{* * * \mathbf{b}}$ & $20.90 \pm 0.77^{* * * \mathbf{b}}$ \\
\hline $\mathrm{Er}-1250 \mathrm{mg} / \mathrm{kg}+\mathrm{CCl}_{4}$ & $223.0 \pm 4.78^{\mathbf{b}}$ & $192.83 \pm 4.85^{\mathrm{b}}$ & $24.91 \pm 0.54^{\mathrm{b}}$ & $159.5 \pm 4.3^{\mathbf{b}}$ & $38.56 \pm 0.97^{\mathbf{b}}$ \\
\hline $\mathrm{Er}-1500 \mathrm{mg} / \mathrm{kg}+\mathrm{CCl}_{4}$ & $211.16 \pm 4.4^{\mathrm{b}}$ & $187.5 \pm 5.2^{\mathrm{b}}$ & $26.43 \pm 0.39^{* * \mathbf{b}}$ & $147.23 \pm 3.76^{* \mathbf{b}}$ & $37.50 \pm 1.04^{\mathrm{b}}$ \\
\hline $\mathrm{Er}-2250 \mathrm{mg} / \mathrm{kg}+\mathrm{CCl}_{4}$ & $186.1 \pm 4.5^{* * * \mathbf{b}}$ & $157.5 \pm 3.7^{* * * \mathbf{b}}$ & $31.4 \pm 1.0^{* * * \mathbf{b}}$ & $123.1 \pm 4.7^{* * * \mathbf{b}}$ & $31.50 \pm 0.74^{* * * \mathbf{b}}$ \\
\hline $\mathrm{Er}-2500 \mathrm{mg} / \mathrm{kg}+\mathrm{CCl}_{4}$ & $155.5 \pm 4.1^{* * * \mathbf{b}}$ & $137.0 \pm 3.8^{* * * \mathbf{b}}$ & $38.40 \pm 0.89^{* * * \mathbf{b}}$ & $89.7 \pm 4.11^{* * * \mathbf{b}}$ & $27.4 \pm 0.77^{* * * \mathbf{b}}$ \\
\hline $\mathrm{Er}-3250 \mathrm{mg} / \mathrm{kg}+\mathrm{CCl}_{4}$ & $150.3 \pm 3.3^{* * * \mathbf{b}}$ & $128.6 \pm 3.4^{* * * \mathbf{b}}$ & $35.41 \pm 0.88^{* * * \mathbf{b}}$ & $89.1 \pm 4.19^{* * * \mathbf{b}}$ & $25.72 \pm 0.76^{* * * \mathbf{b}}$ \\
\hline $\mathrm{Er}-3500 \mathrm{mg} / \mathrm{kg}+\mathrm{CCl}_{4}$ & $129.6 \pm 8.3^{* * * \mathbf{b}}$ & $125.8 \pm 3.4 \pm^{* * * \mathbf{b}}$ & $40.81 \pm 1.21^{* * * \mathbf{b}}$ & $63.6 \pm 3.8^{* * * b}$ & $25.16 \pm 0.68^{* * * \mathbf{b}}$ \\
\hline $\mathrm{Er}-4250 \mathrm{mg} / \mathrm{kg}+\mathrm{CCl}_{4}$ & $219.83 \pm 7.5^{\mathbf{b}}$ & $180.16 \pm 7.4^{\mathrm{b}}$ & $25.58 \pm 1.13^{\mathrm{b}}$ & $161.2 \pm 9.4^{\mathrm{b}}$ & $36.03 \pm 1.48^{\mathbf{b}}$ \\
\hline $\mathrm{Er}-4500 \mathrm{mg} / \mathrm{kg}+\mathrm{CCl}_{4}$ & $215.66 \pm 4.4^{\mathrm{b}}$ & $166.33 \pm 5.16^{* \mathbf{b}}$ & $27.58 \pm 0.92^{* * \mathbf{b}}$ & $154.8 \pm 4.8^{\mathrm{b}}$ & $33.26 \pm 1.03^{* * \mathbf{b}}$ \\
\hline
\end{tabular}

All values represent mean \pm SEM. ${ }^{*} \mathrm{P}<0.05 ;{ }^{* *} \mathrm{P}<0.01 ;{ }^{* * *} \mathrm{P}<0.001$; ANOVA, followed by Dennett's multiple comparison test. ${ }^{\text {a }}$ As compared to that of the control group; ${ }^{\mathbf{b}}$ as compared to that of the $\mathrm{CCl}_{4}$ positive control group.

$<0.01$, and $\mathrm{P}<0.001)$ among the groups was determined by one-way analysis of variance (ANOVA) followed by Dennett's multiple comparison test.

\section{Results}

3.1. Biochemical Results. Biochemical parameters of the normal control group were designated as baseline values. Serum ALP, AST, ALT, GGT, and bilirubin levels were considerably higher in the $\mathrm{CCl}_{4}$ group than in the control group. Those levels were considerably lower in the silymarin group than in the $\mathrm{CCl}_{4}$ group. Administration of 250 and 500 $\mathrm{mg} / \mathrm{kg}$ of Er-1, Er-2, Er-3, and Er-4 in $\mathrm{CCl}_{4}$-treated rats significantly reduced the levels of ALT, AST, ALP, GGT, and bilirubin compared to those of the $\mathrm{CCl}_{4}$ positive control group (Table 1). Moreover, extracts and fractions+ $\mathrm{CCl}_{4}$ treated rats did not have significantly different cholesterol, triglyceride, LDL, HDL, and VLDL levels than did the normal control group (Table 2). Thus, E. japonica leaf extract and its fractions had noticeable hepatoprotective activity against $\mathrm{CCl}_{4}$-induced hepatotoxicity.

MDA levels indicated that lipid peroxidation was significantly higher in the $\mathrm{CCl}_{4}$ group than in the normal control group $(\mathrm{P}<0.001)$. Pretreatment with silymarin at $10 \mathrm{mg} / \mathrm{kg}$ significantly reduced MDA to levels that nearly matched those of the control group. Although the MDA levels of $\mathrm{CCl}_{4}$-treated rats that were preadministered low dose (250 mg/kg) Er-1 did not significantly differ from those of the $\mathrm{CCl}_{4}$ positive control group, the MDA levels of $\mathrm{CCl}_{4}$ treated rats in preadministered high dose $(500 \mathrm{mg} / \mathrm{kg})$ of Er1 were significantly lower than those of the $\mathrm{CCl}_{4}$ positive control group $(\mathrm{P}<0.001)$. Postreatment of $\mathrm{CCl}_{4}$-treated with low- or high dose Er-2 significantly reduced MDA levels as compared to those of the $\mathrm{CCl}_{4}$ positive control group 
TABLE 3: Effect of E. japonica leaf extract and fractions on MDA, NP-SH, and total protein levels in liver tissues.

\begin{tabular}{|c|c|c|c|}
\hline Treatments & $\begin{array}{c}\text { MDA } \\
(\mathbf{n m o l} / \mathrm{g})\end{array}$ & $\begin{array}{l}\text { NP-SH } \\
(\mathbf{n m o l} / \mathrm{g})\end{array}$ & Total Protein $(\mathrm{g} / \mathrm{L})$ \\
\hline Normal & $1.11 \pm 0.04$ & $6.33 \pm 0.28$ & $121.35 \pm 3.36$ \\
\hline $\mathrm{CCl}_{4}$ & $7.43 \pm 0.29^{* * * a}$ & $1.41 \pm 0.21^{* * * a}$ & $59.48 \pm 1.89^{* * * a}$ \\
\hline Silymarin $(10 \mathrm{mg} / \mathrm{kg})+\mathrm{CCl}_{4}$ & $2.15 \pm 0.09^{* * * \mathbf{b}}$ & $5.91 \pm 0.26^{* * * \mathbf{b}}$ & $106.98 \pm 2.28^{* * * b}$ \\
\hline $\operatorname{Er}-1(250 \mathrm{mg} / \mathrm{kg})+\mathrm{CCl}_{4}$ & $6.76 \pm 0.38^{b}$ & $1.77 \pm 0.29^{b}$ & $59.88 \pm 2.31^{\mathbf{b}}$ \\
\hline $\mathrm{Er}-1(500 \mathrm{mg} / \mathrm{kg})+\mathrm{CCl}_{4}$ & $5.59 \pm 0.24^{* * * \mathbf{b}}$ & $2.20 \pm 0.25^{* \mathbf{b}}$ & $66.66 \pm 1.68^{* \mathbf{b}}$ \\
\hline $\mathrm{Er}-2(250 \mathrm{mg} / \mathrm{kg})+\mathrm{CCl}_{4}$ & $4.25 \pm 0.18^{* * * \mathrm{~b}}$ & $4.81 \pm 0.21^{* * * \mathbf{b}}$ & $73.45 \pm 1.00^{* * * \mathbf{b}}$ \\
\hline $\mathrm{Er}-2(500 \mathrm{mg} / \mathrm{kg})+\mathrm{CCl}_{4}$ & $3.60 \pm 0.12^{* * * \mathbf{b}}$ & $5.13 \pm 0.28^{* * * \mathbf{b}}$ & $81.83 \pm 1.89^{* * * \mathbf{b}}$ \\
\hline $\mathrm{Er}-3(250 \mathrm{mg} / \mathrm{kg})+\mathrm{CCl}_{4}$ & $3.60 \pm 0.19^{* * * \mathbf{b}}$ & $5.31 \pm 0.13^{* * * \mathbf{b}}$ & $77.44 \pm 2.59^{* * * \mathbf{b}}$ \\
\hline $\mathrm{Er}-3(500 \mathrm{mg} / \mathrm{kg})+\mathrm{CCl}_{4}$ & $2.79 \pm 0.10^{* * * \mathbf{b}}$ & $5.00 \pm 0.27^{* * * \mathbf{b}}$ & $95.80 \pm 2.83^{* * * \mathbf{b}}$ \\
\hline $\mathrm{Er}-4(250 \mathrm{mg} / \mathrm{kg})+\mathrm{CCl}_{4}$ & $6.87 \pm 0.3^{\mathbf{b}}$ & $1.52 \pm 0.2^{\mathrm{b}}$ & $58.68 \pm 1.60^{\mathrm{b}}$ \\
\hline $\mathrm{Er}-4(500 \mathrm{mg} / \mathrm{kg})+\mathrm{CCl}_{4}$ & $5.52 \pm 0.21^{* * * \mathbf{b}}$ & $2.50 \pm 0.28^{* \mathbf{b}}$ & $67.46 \pm 1.43^{* * \mathbf{b}}$ \\
\hline
\end{tabular}

All values represent mean \pm SEM. ${ }^{*} \mathrm{P}<0.05 ;{ }^{* *} \mathrm{P}<0.01 ;{ }^{* * *} \mathrm{P}<0.001$; ANOVA, followed by Dennett's multiple comparison test. ${ }^{\text {a }}$ As compared to that of the control group; ${ }^{\mathrm{b}}$ as compared to that of the $\mathrm{CCl}_{4}$ positive control group.

$(\mathrm{P}<0.001)$. Similarly, treatment of $\mathrm{CCl}_{4}$-treated rats with low- or high dose Er-3 significantly reduced MDA levels as compared to those of the $\mathrm{CCl}_{4}$ positive control group $(\mathrm{P}<$ 0.001). Whereas rats treated with low dose $\mathrm{Er}-4$ did not have significantly lower MDA levels than those in the $\mathrm{CCl}_{4}$ positive control group, those treated with high dose Er-4 experienced a significant reduction in MDA levels (Table 3 ).

In $\mathrm{CCl}_{4}$-treated rat's preadministered low $(250 \mathrm{mg} / \mathrm{kg})$ or high $(500 \mathrm{mg} / \mathrm{kg})$ doses of Er-1 or Er-4, there was insignificant recovery of NP-SH levels as compared to those of the $\mathrm{CCl}_{4}$ group. However, samples of Er-2 or Er-3 at doses of 250 or $500 \mathrm{mg} / \mathrm{kg}$ caused significant increases in NP-SH levels as compared to those of the $\mathrm{CCl}_{4}$ positive control group (Table 3).

Treatment of animals with $\mathrm{CCl}_{4}$ agents led to depletion of total protein. Pretreatment of test animals with silymarin significantly increased total protein levels as compared to those of the $\mathrm{CCl}_{4}$ positive control group; their total protein levels approached those of the normal control group. The total protein levels of rats that received low or high doses of Er-4 did not significantly differ from those of the $\mathrm{CCl}_{4}$ positive control group. In contrast, rats given low or high doses of Er-2 or Er-3 had significantly higher total protein levels than those of the $\mathrm{CCl}_{4}$ positive control group (Table 3).

3.2. Histopathological Results. Microscopic histological inspection of the liver segments of normal control rats is baseline images with normal hepatocytes, and the hepatic sinusoids appeared to be lined by Kupffer cells (Figure 1(a)). In comparison, the hepatic lobules of $\mathrm{CCl}_{4}$ positive control rats showed severely distorted structures, congestion of the central veins and hepatic sinusoids, and inflammatory cell infiltration (Figure 1(b)). The hepatocytes of animals that were coadministered silymarin and $\mathrm{CCl}_{4}$ had normal architecture that resembled that of the normal control group (Figure 1(c)).

In $\mathrm{CCl}_{4}$-treated rats supplemented with low dose (250 $\mathrm{mg} / \mathrm{kg}$ ) Er-1, the hepatocytes did not completely recover; a portion of their livers had mild cellular swelling and moderate hepatocyte necrosis (Figure $1(\mathrm{~d})$ ). Rats treated with $\mathrm{CCl}_{4}$ and presupplemented with high dose $(500 \mathrm{mg} / \mathrm{kg})$ of Er-1 had normal hepatic lobules, but their hepatocytes were not normal (Figure 1(e)).

Hepatocytes did not recover to normal in $\mathrm{CCl}_{4}$-treated rats supplemented with low dose $(250 \mathrm{mg} / \mathrm{kg})$ of Er- 2 . Their liver slices revealed slight cellular swelling and moderate focal necrosis of hepatocytes (Figure $1(\mathrm{f})$ ). However, $\mathrm{CCl}_{4}$ treated rats supplemented with high dose $(500 \mathrm{mg} / \mathrm{kg})$ of Er2 showed normal hepatic lobules and normal hepatocytes (Figure 1(g)).

Histopathological examination of livers from $\mathrm{CCl}_{4}$ treated rat's preadministered low dose $(250 \mathrm{mg} / \mathrm{kg})$ of Er3 showed abnormal hepatocytes, with mild cellular swelling and focal necrosis that is associated with inflammatory infiltration (Figure 1(h)). However, the livers of those supplemented with high dose $(500 \mathrm{mg} / \mathrm{kg})$ of $\mathrm{Er}-3$ showed imprecise structural design, with vacuolated cytoplasm and cellular necrosis. Cell penetration was also detected in their hepatic lobules (Figure 1(i)).

Finally, $\mathrm{CCl}_{4}$-treated rats presupplemented with low dose $(250 \mathrm{mg} / \mathrm{kg})$ of Er-4 showed distorted architecture of the hepatic lobules that is associated with mild hepatocytic swelling (Figure $1(\mathrm{j})$ ). In $\mathrm{CCl}_{4}$-treated rats that were administered high dose $(500 \mathrm{mg} / \mathrm{kg})$ of Er-4, the scale of liver injury was miniscule and hepatic lobules were normal; however, fatty changes were observed (Figure 1(k)).

\section{Discussion}

The liver is the primary organ for controlling vital functions such as digestion and detoxification of most compounds that enter the body $[18,19]$. Much attention is currently focused on research involving the pharmacological applications of plant extracts and their fractions. The present study was conducted to compare the hepatoprotective effects of E. japonica extract and its various fractions against $\mathrm{CCl}_{4}$-induced hepatotoxicity in rats. 


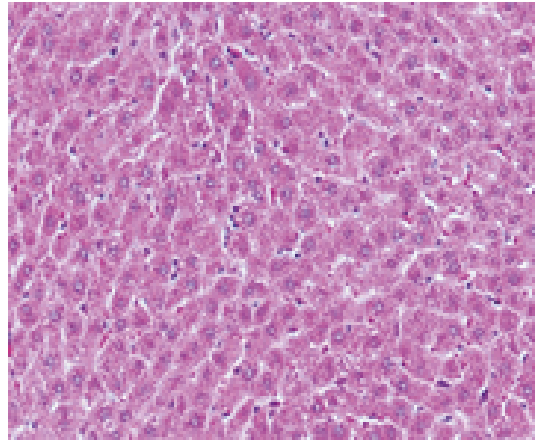

(a) Normal

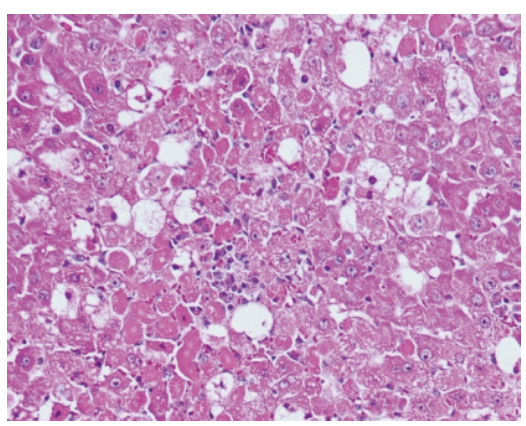

(d) $\operatorname{Er}-1(250 \mathrm{mg} / \mathrm{kg})$

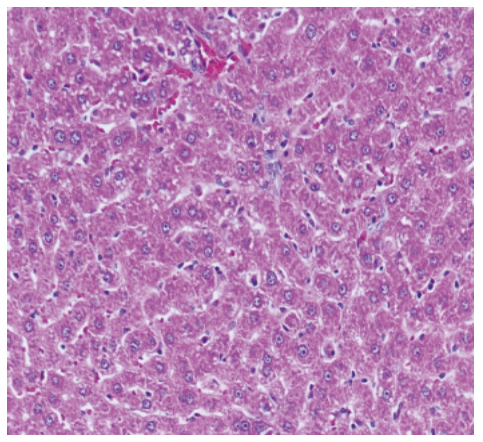

(g) Er-2 $(500 \mathrm{mg} / \mathrm{kg})$

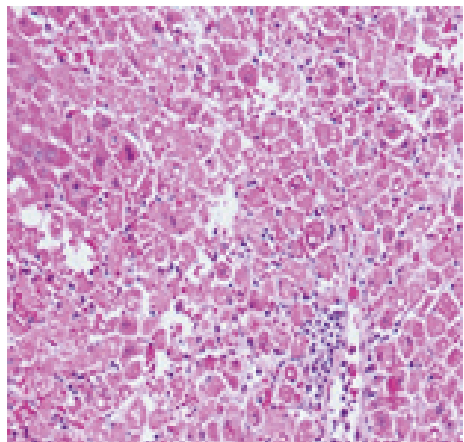

(b) $\mathrm{CCl}_{4}$ Only

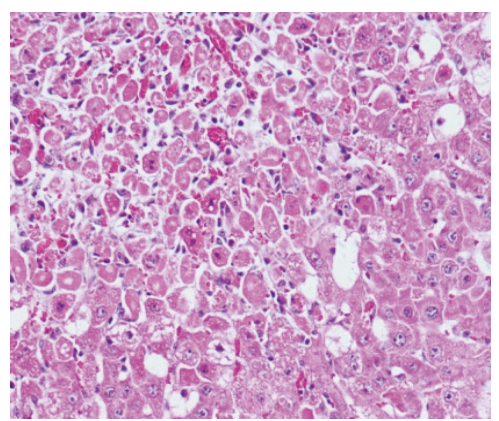

(e) $\operatorname{Er}-1(500 \mathrm{mg} / \mathrm{kg})$

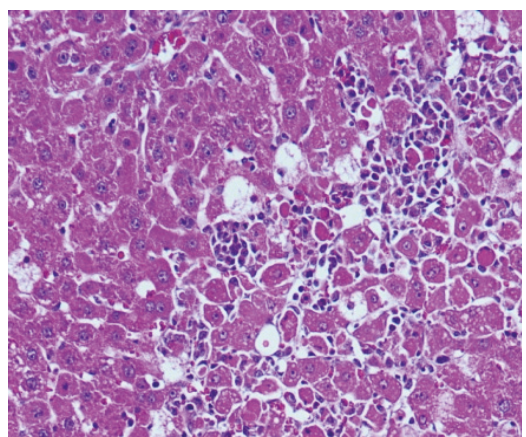

(h) Er-3 $(250 \mathrm{mg} / \mathrm{kg})$

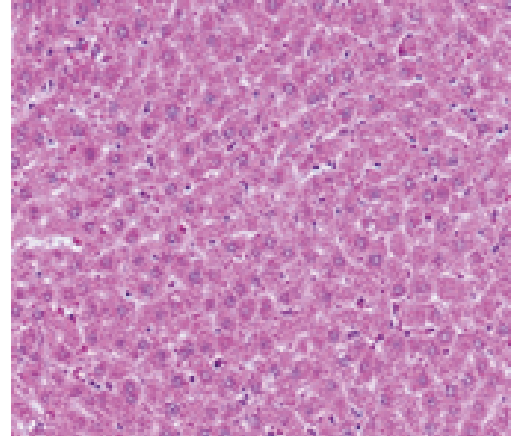

(c) Silymarin

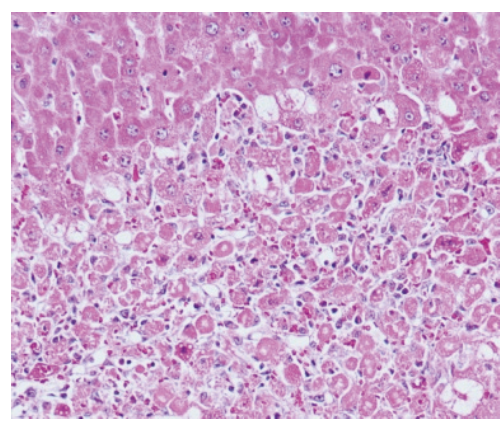

(f) $\operatorname{Er}-2(250 \mathrm{mg} / \mathrm{kg})$

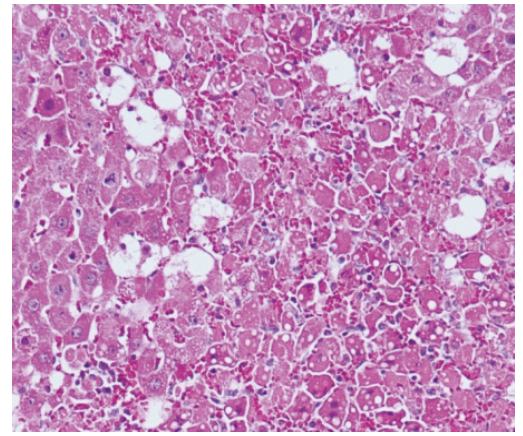

(i) $\operatorname{Er}-3(500 \mathrm{mg} / \mathrm{kg})$

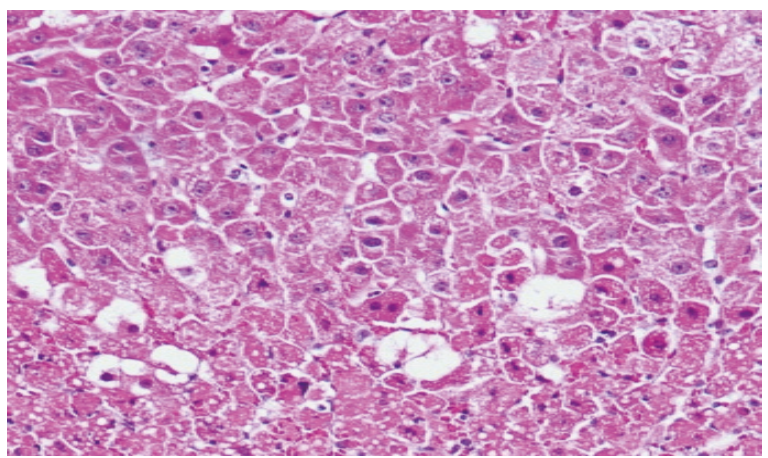

(j) $\operatorname{Er}-4(250 \mathrm{mg} / \mathrm{kg})$

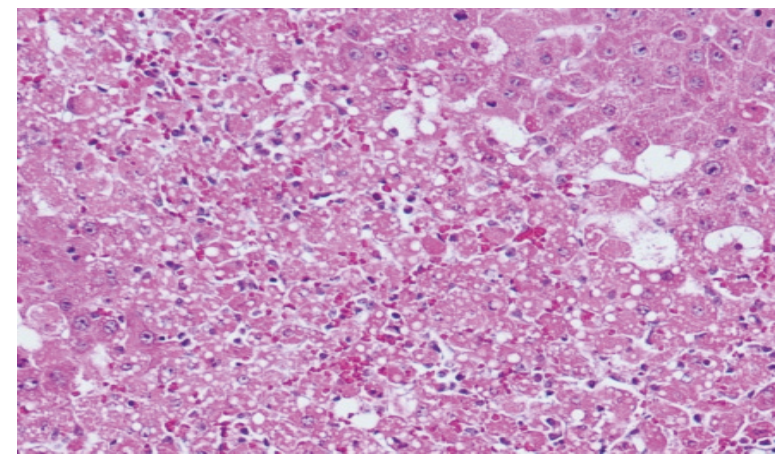

(k) $\operatorname{Er}-4(500 \mathrm{mg} / \mathrm{kg})$

FIGURE 1: Histopathological examination of rat liver tissues $(\mathrm{H} \& \mathrm{E}$ stain $\times 150)$. 
$\mathrm{CCl}_{4}$ is widely used to induce liver injury because its metabolism by hepatic cytochrome P450 leads to the generation of highly reactive carbon-centered trichloromethyl radicals. Such free radicals initiate lipid peroxidation chain reactions to cause liver damage $[20,21]$. MDA, an end product of lipid peroxidation in the liver, is an important indicator of $\mathrm{CCl}_{4}$-induced toxicity in rats [22]. In the present study, high MDA levels indicated that lipid peroxidation rates were significantly greater in the $\mathrm{CCl}_{4}$ positive control group than in the normal control group. Preadministration of high doses of Er-1, Er-2, Er-3, or Er-4 significantly attenuated the $\mathrm{CCl}_{4}$ induced elevation of MDA levels.

Studies have shown that trichloromethyl radicals of $\mathrm{CCl}_{4}$ (the active metabolites of $\mathrm{CCl}_{4}$ ) bind covalently to macromolecules and induce peroxidative degradation of membrane lipids of endoplasmic reticuli rich in polyunsaturated fatty acids. This process leads to excessive formation and accumulation of lipids in tissues such as the liver. In addition, lipids from peripheral adipose tissue are translocated to the liver for accumulation $[23,24]$. In the present study, $\mathrm{CCl}_{4}$ treatment reduced HDL levels and raised serum cholesterol, triglyceride, and LDL levels, which possibly reflects impairment of the liver cells' ability to metabolize lipids and transform cholesterol to bile acid for excretion. Eriobotrya japonica extract and its various fractions attenuated those effects.

Our results showed that $\mathrm{CCl}_{4}$ raised the levels of SGPT, SGOT, ALP, and bilirubin in rat serum. Such enzymes are normally present at higher levels in cell cytoplasm than in the serum. Hepatopathy causes release of AST, ALT, and bilirubin into the bloodstream in proportion to the extent of liver damage [25]. In our study, the elevation of serum AST, ALT, ALP, and total bilirubin levels in $\mathrm{CCl}_{4}$-treated rats indicated cellular damage and loss of cell membrane function [26]. This was confirmed by histopathological examination of their liver sections, which showed congestion of the central veins and hepatic sinusoids, inflammatory cell infiltration, and severe architectural distortion that is associated with cellular necrosis and vacuolated cytoplasm. Administration of various formulations of loquat leaves attenuated the $\mathrm{CCl}_{4}$ induced elevation of SGPT, SGOT, ALP, and bilirubin levels. The effects of the leaf formulations were possibly due to the presence of flavonoids.

Studies [25, 27] have reported that many herbs are an excellent source of phenolic compounds that possess antioxidant effects. Along the same vein, several studies have shown that loquat leaves have antioxidant effects $[28,29]$. Natural antioxidants express their antioxidant properties by blocking lipid peroxidation via inhibition of the enzyme xanthine oxidase [29]; direct scavenging of hydroxyl, peroxyl, and superoxide radicals [30]; and inhibition of structural damage to proteins [31].

$\mathrm{CCl}_{4}$ causes disruption and disassociation of polyribosomes on the endoplasmic reticulum, which leads to reduction of protein biosynthesis [32]. In our study, the injection of animals with $\mathrm{CCl}_{4}$ caused depletion of total proteins, which indicates liver toxicity [33]. Whereas administration of Er-2 or Er-3 significantly attenuated $\mathrm{CCl}_{4}$-induced total protein depletion, administration of Er-1 or Er-4 did not.
The $\mathrm{CCl}_{4}$ positive control group had significantly lower NP-SH levels than did the normal control group. Administration of $10 \mathrm{mg} / \mathrm{kg}$ silymarin significantly reduced NP$\mathrm{SH}$ levels below those of the $\mathrm{CCl}_{4}$ positive control group. The recovery of the NP-SH levels after treatment with silymarin was closer to that observed in the normal control group. Furthermore, whereas administration of Er-2 or Er-3 significantly attenuated the $\mathrm{CCl}_{4}$-induced reduction of NPSH levels, administration of Er-1 or Er-4 did not (Table 3).

In summary, lipid peroxidation is associated with the pathogenesis of hepatic injury that is induced by the free radical reactive intermediates of $\mathrm{CCl}_{4}$ degradation. Lipid peroxidation is responsible for the damage to cell membranes that results in discharge of the enzymatic markers for hepatotoxicity [34]. In our study, $\mathrm{CCl}_{4}$ induced a marked increase in liver MDA levels that resulted in liver injury. Pretreatment with 250 or $500 \mathrm{mg} / \mathrm{kg}$ of Er-1, Er-2, Er-3, and Er4 attenuated the $\mathrm{CCl}_{4}$-induced elevation of MDA enzymes, which was confirmed by the reduction in histopathological injuries.

Many researchers suggested the proposed mechanism is reducing proinflammatory mediators or increasing antiinflammatory cytokine (such as IL-10) discharges are significant mechanisms for the anti-inflammation effects of loquat extracts $[8,13,14,18-21]$. Such regulation was linked with restraining the activation and expression of the nuclear factor- $\kappa \mathrm{B}(\mathrm{NF}-\kappa \mathrm{B})[18,19,22-24]$ and/or mitogen-activated protein kinase (MAPK) signaling pathway $[15,22,23]$, which have been suggested as key regulators of the expression of inflammatory mediators in the cellular signaling pathway $[4,5,35-39]$

The relative levels of hepatoprotection afforded by the extract and fractions were as follows: Er-2 $>$ Er-3 $>$ Er-4 $>$ Er-1.

\section{Conclusion}

The above results suggest that Er-1, Er-2, Er-3, and Er-4 have hepatoprotective activity and that such activity is conferred through their ability to reduce the lipid peroxidation rate, promote antioxidant effects, and inhibit $\mathrm{CCl}_{4}$-induced pathological changes in the liver. Er-2 and Er-3 are more effective at protecting the liver from damage than Er-1 and Er-4 and recommended for further bioscreening natural products.

\section{Data Availability}

All data obtained during this study are included in this article. The data or any material can also be obtained from corresponding author upon reasonable request.

\section{Ethical Approval}

All animals were retained as per the approvals of the "Guide for the Care and Use of Laboratory Animals" as permitted by the institutional animal ethics committee of the College of Pharmacy, King Saud University, Riyadh, Saudi Arabia (clearance no. 05763-891; January 6, 2014). 


\section{Conflicts of Interest}

The authors declare that they have no conflicts of interest.

\section{Authors' Contributions}

Abdelaaty A. Shahat, Riaz Ullah, and Ali S. Alqahtani equally contributed to this work. Abdelaaty A. Shahat and Riaz Ullah conducted the experiment, Ali S. Alqahtani and Mansour S. Alsaid designed the study, and Husseiny A. Husseiny and Osaid T. R. Al Meanazel composed and reviewed final manuscript. All authors have read and approved the final manuscript.

\section{Acknowledgments}

The authors extend their appreciation to the Deanship of Scientific Research at King Saud University for funding support (Research Group no. RGP-262).

\section{References}

[1] World Health Organization, "Summary of WHO guidelines for the assessment of herbal medicines," HerbalGram, vol. 28, pp. 13-14, 1993.

[2] H. Ito, E. Kobayashi, Y. Takamatsu et al., "Polyphenols from Eriobotrya japonica and their cytotoxicity against human oral tumor cell lines," Chemical \& Pharmaceutical Bulletin, vol. 48, no. 5, pp. 687-693, 2000.

[3] K. Koba, A. Matsuoka, K. Osada, and Y.-S. Huang, "Effect of loquat (Eriobotrya japonica) extracts on LDL oxidation," Food Chemistry, vol. 104, no. 1, pp. 308-316, 2007.

[4] D. S. Cha, J. S. Eun, and H. Jeon, "Anti-inflammatory and antinociceptive properties of the leaves of Eriobotrya japonica," Journal of Ethnopharmacology, vol. 134, no. 2, pp. 305-312, 2011.

[5] S.-H. Kim and T.-Y. Shin, "Anti-inflammatory effect of leaves of Eriobotrya japonica correlating with attenuation of p38 MAPK, ERK, and NF- $\kappa$ B activation in mast cells," Toxicology in Vitro, vol. 23, no. 7, pp. 1215-1219, 2009.

[6] S. Taniguchi, Y. Imayoshi, E. Kobayashi et al., "Production of bioactive triterpenes by Eriobotrya japonica calli," Phytochemistry, vol. 59, no. 3, pp. 315-323, 2002.

[7] H. Lv, J. Chen, W.-L. Li, and H.-Q. Zhang, "Studies on the triterpenes from loquat leaf (Eriobotrya japonica)," Journal of Chinese Medicinal Materials, vol. 31, no. 9, pp. 1351-1354, 2008.

[8] A. S. Fogo, E. Antonioli, J. B. Calixto, and A. H. Campos, "Tormentic acid reduces vascular smooth muscle cell proliferation and survival," European Journal of Pharmacology, vol. 615, no. 1-3, pp. 50-54, 2009.

[9] M. D. Ivorra, M. Paya, and A. Villar, "Hypoglycemic and insulin release effects of tormentic acid: A new hypoglycemic natural product," Planta Medica, vol. 54, no. 4, pp. 282-286, 1988.

[10] A. H. Esmaeili, R. A. Khavari-Nejad, A. Hajizadeh Moghaddam, M. J. Chaichi, and M. A. Ebrahimzadeh, "Effects of Eriobotrya japonica (Lindl.) flower extracts on mercuric chloride-induced hepatotoxicity in rats," Chinese Science Bulletin, vol. 57, no. 30, pp. 3891-3897, 2012.

[11] M. Junnila, T. Rahko, A. Sukura, and L.-A. Lindberg, "Reduction of carbon tetrachloride-induced hepatotoxic effects by oral administration of betaine in male Han-Wistar rats: A morphometric histological study," Veterinary Pathology, vol. 37, no. 3, pp. 231-238, 2000.

[12] E. Karakus, A. Karadeniz, N. Simsek et al., "Protective effect of Panax ginseng against serum biochemical changes and apoptosis in liver of rats treated with carbon tetrachloride $\left(\mathrm{CCl}_{4}\right)$," Journal of Hazardous Materials, vol. 195, pp. 208-213, 2011.

[13] S. Sundaresan and P. Subramanian, "S-allylcysteine inhibits circulatory lipid peroxidation and promotes antioxidants in $\mathrm{N}$ nitrosodiethylamine-induced carcinogenesis," Polish Journal of Pharmacology, vol. 55, no. 1, pp. 37-42, 2003.

[14] N. Vargas-Mendoza, E. Madrigal-Santillan, Ï. Morales-Gonzalez et al., "Hepatoprotective effect of silymarin," World Journal of Hepatology, vol. 6, no. 3, pp. 144-149, 2014.

[15] R. Ullah, M. S. Alsaid, A. A. Shahat et al., "Antioxidant and hepatoprotective effects of methanolic extracts of Zilla spinosa and Hammada elegans against carbon tetrachlorideinduced hepatotoxicity in rats," Open Chemistry, vol. 16, no. 1, pp. 133140,2018

[16] M. S. Al-Said, R. A. Mothana, M. M. Al-Yahya et al., "GCMS analysis: In vivo hepatoprotective and antioxidant activities of the essential oil of Achillea biebersteinii afan. Growing in Saudi Arabia," Evidence-Based Complementary and Alternative Medicine, vol. 2016, Article ID 1867048, 8 pages, 2016.

[17] J. D. Bancroft, A. Stevens, and M. P. Dawson, Theory and Practice of Histological Techniques, Churchill Livingstone, London, UK, 4th edition, 1996.

[18] G. Giannelli, V. Quaranta, and S. Antonaci, "Tissue remodelling in liver diseases," Histology and Histopathology, vol. 18, no. 4, pp. 1267-1274, 2003.

[19] M. Núñez, "Hepatotoxicity of antiretrovirals: incidence, mechanisms and management," Journal of Hepatology, vol. 44, no. 1 , pp. S132-S139, 2006.

[20] L. W. D. Weber, M. Boll, and A. Stampfl, "Hepatotoxicity and mechanism of action of haloalkanes: carbon tetrachloride as a toxicological model," Critical Reviews in Toxicology, vol. 33, no. 2, pp. 105-136, 2003.

[21] H.-L. Fang, J.-T. Lai, and W.-C. Lin, "Inhibitory effect of olive oil on fibrosis induced by carbon tetrachloride in rat liver," Clinical Nutrition, vol. 27, no. 6, pp. 900-907, 2008.

[22] M. F. Souza, V. S. N. Rao, and E. R. Silveira, "Inhibition of lipid peroxidation by ternatin, a tetramethoxyflavone from Egletes viscosa L," Phytomedicine, vol. 4, no. 1, pp. 27-31, 1997.

[23] J. G. M. Bessems and N. P. E. Vermeulen, "Paracetamol (acetaminophen)-induced toxicity: molecular and biochemical mechanisms, analogues and protective approaches," Critical Reviews in Toxicology, vol. 31, no. 1, pp. 55-138, 2001.

[24] S. P. Srivastava, N. Chen, and J. L. Holtzman, "The in vitro $\mathrm{NADPH}$-dependent inhibition by $\mathrm{CCl} 4$ of the ATP-dependent calcium uptake of hepatic microsomes from male rats: studies on the mechanism of the inactivation of the hepatic microsomal calcium pump by the $\mathrm{CCL}_{3}$ radical," The Journal of Biological Chemistry, vol. 265, no. 15, pp. 8392-8399, 1990.

[25] C. Z. Nkosi, A. R. Opoku, and S. E. Terblanche, "Effect of pumpkin seed (Cucurbita pepo) protein isolate on the activity levels of certain plasma enzymes in CCl4-induced liver injury in low-protein fed rats," Phytotherapy Research, vol. 19, no. 4, pp. 341-345, 2005.

[26] H. Zeashan, G. Amresh, S. Singh, and C. V. Rao, "Hepatoprotective activity of Amaranthus spinosus in experimental animals," Food and Chemical Toxicology, vol. 46, no. 11, pp. 3417-3421, 2008 . 
[27] P. L. Teissedre and A. L. Waterhouse, "Inhibition of oxidation of human low-density lipoproteins by phenolic substances in different essential oils varieties," Journal of Agricultural and Food Chemistry, vol. 48, no. 9, pp. 3801-3805, 2000.

[28] N. Banno, T. Akihisa, H. Tokuda et al., "Anti-inflammatory and antitumor-promoting effects of the triterpene acids from the leaves of Eriobotrya japonica," Biological \& Pharmaceutical Bulletin, vol. 28, no. 10, pp. 1995-1999, 2005.

[29] Y. Hong, S. Lin, Y. Jiang, and M. Ashraf, "Variation in contents of total phenolics and flavonoids and antioxidant activities in the leaves of 11 Eriobotrya species," Plant Foods for Human Nutrition, vol. 63, no. 4, pp. 200-204, 2008.

[30] C. V. de Whalley, S. M. Rankin, J. R. S. Hoult, W. Jessup, and D. S. Leake, "Flavonoids inhibit the oxidative modification of low density lipoproteins by macrophages," Biochemical Pharmacology, vol. 39, no. 11, pp. 1743-1750, 1990.

[31] A. Salvi, P. Carrupt, J. Tillement, and B. Testa, "Structural damage to proteins caused by free radicals: asessment, protection by antioxidants, and influence of protein binding," Biochemical Pharmacology, vol. 61, pp. 1237-1242, 2001.

[32] S. S. Kumar, B. R. Kumar, and G. K. Mohan, "Hepatoprotective effect of Trichosanthes cucumerina var cucumerina L. on carbon tetrachloride induced liver damage in rats," Journal of Ethnopharmacology, vol. 123, no. 2, pp. 347-350, 2009.

[33] S. Ravikumar and M. Gnanadesigan, "Hepatoprotective and antioxidant properties of rhizophora mucronata mangrove plant in CCl 4 intoxicated rats," Journal of Experimental \& Clinical Medicine, vol. 4, no. 1, pp. 66-72, 2012.

[34] O. Danni, E. Chiarpotto, M. Aragno et al., "Lipid peroxidation and irreversible cell damage: Synergism between carbon tetrachloride and 1,2-dibromoethane in isolated rat hepatocytes," Toxicology and Applied Pharmacology, vol. 110, no. 2, pp. 216222, 1991.

[35] J.-F. Ge, T.-Y. Wang, B. Zhao et al., "Anti-inflammatory effect of triterpenoic acids of Eriobotrya japonica (Thunb.) Lindl. Leaf on rat model of chronic bronchitis," American Journal of Chinese Medicine, vol. 37, no. 2, pp. 309-321, 2009.

[36] C.-H. Lee, S.-L. Wu, J.-C. Chen et al., "Eriobotrya japonica leaf and its triterpenes inhibited lipopolysaccharide-induced cytokines and inducible enzyme production via the nuclear factor- $\kappa \mathrm{B}$ signaling pathway in lung epithelial cells," American Journal of Chinese Medicine, vol. 36, no. 6, pp. 1185-1198, 2008.

[37] K. Z. Matalka, D. Ali, A. E. Khawad, and F. Qa'dan, “The differential effect of Eriobotrya japonica hydrophilic leaf extract on cytokines production and modulation," Cytokine, vol. 40, no. 3, pp. 235-240, 2007.

[38] T. Uto, N. Suangkaew, O. Morinaga, H. Kariyazono, S. Oiso, and Y. Shoyama, "Eriobotryae folium extract suppresses LPSinduced iNOS and COX-2 expression by inhibition of NF$\kappa \mathrm{B}$ and MAPK activation in murine macrophages," American Journal of Chinese Medicine, vol. 38, no. 5, pp. 985-994, 2010.

[39] Y. Huang, J. Li, X. M. Meng et al., "Effect of triterpene acids of Eriobotrya japonica (Thunb.) Lindl. Leaf and MAPK signal transduction pathway on inducible nitric oxide synthase expression in alveolar macrophage of chronic bronchitis rats," American Journal of Chinese Medicine, vol. 37, no. 6, pp. 10991111, 2009. 


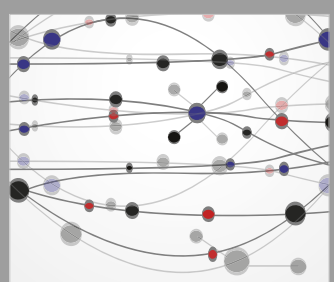

The Scientific World Journal
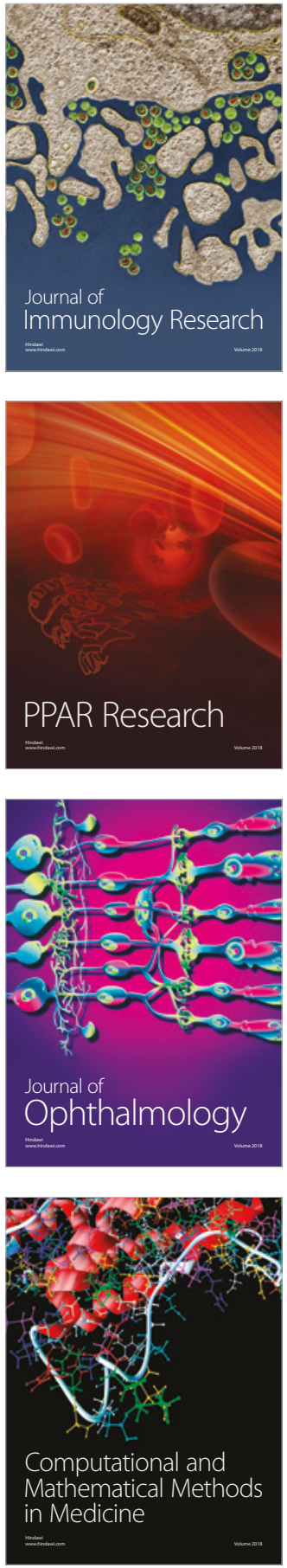

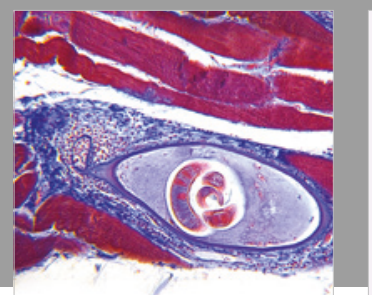

Gastroenterology Research and Practice

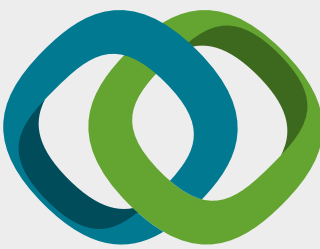

\section{Hindawi}

Submit your manuscripts at

www.hindawi.com
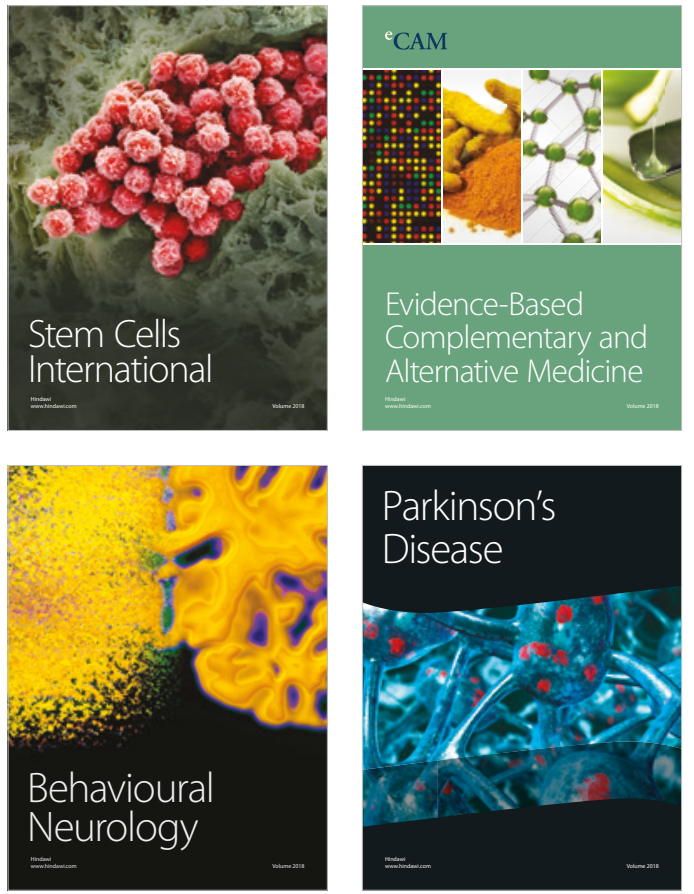

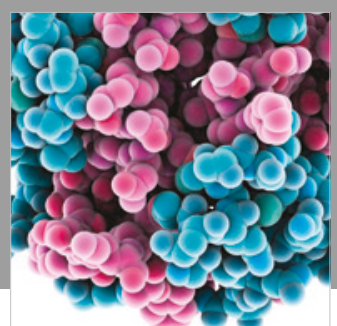

ournal of

Diabetes Research

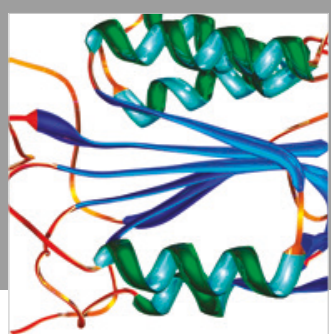

Disease Markers
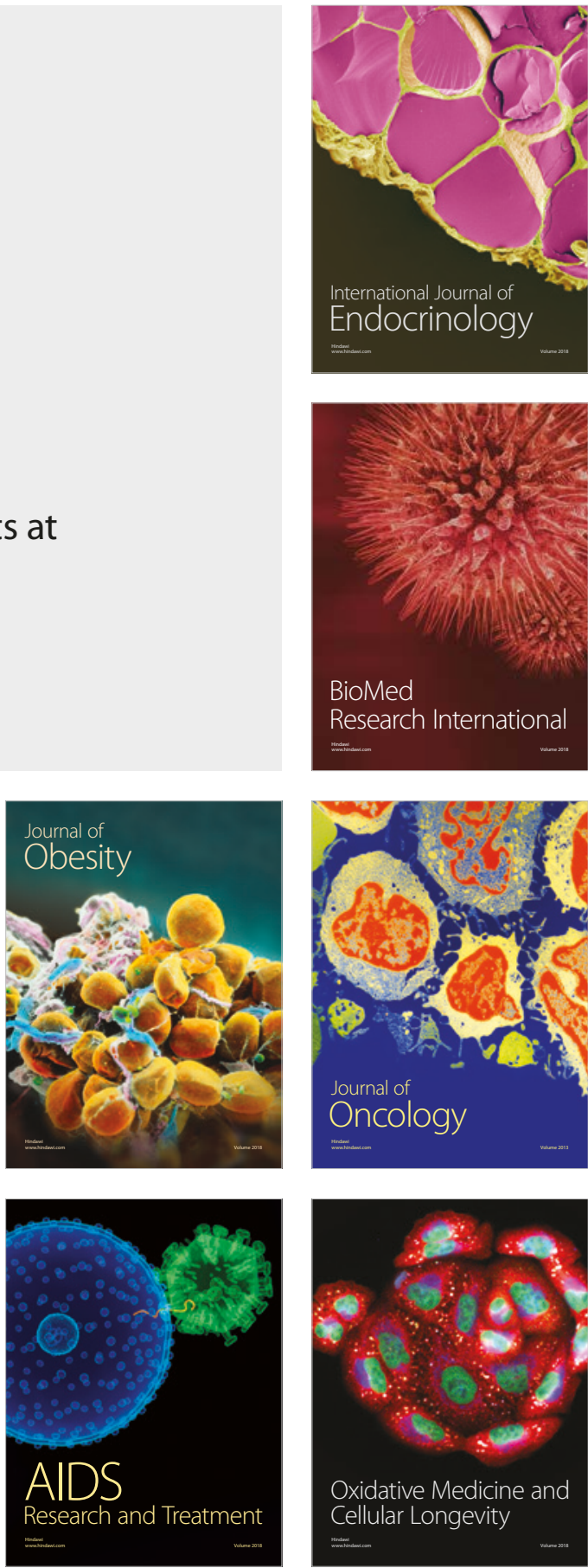